\title{
NORMAL VALUES OF TISSUE-MUSCLE PERFUSION INDEXES OF LOWER LIMBS OBTAINED WITH A SCINTIGRAPHIC METHOD
}

\author{
Nevena Manevska ${ }^{1}$, Sinisa Stojanoski ${ }^{1}$, Daniela Pop Gjorceva ${ }^{1}$, Lidija Todorovska $^{2}$, \\ Daniela Miladinova $^{1}$, Beti Zafirova ${ }^{3}$
${ }^{1}$ Institute of Pathophysiology and Nuclear Medicine, Acad “Isak S. Tadzer”, Medical Faculty, Skopje, R. MacedoniaUniver- sity Cardiology Clinic, University Stt Cyril and Methodius Skopje, Macedonia
${ }^{2}$ Institute of Medical Physiology and Antropology, Medical Faculty, Skopje, R.Macedonia
${ }^{3}$ Institute of Epidemiology and Biostatistics with Medical Informatics, Medical Faculty, Skopje, R. Macedonia

Corresponding author: Nevena Manevska, str. Mother Theresa No 17, Skopje, Macedonia, tel.: +39070398042, dr.nmanevska@gmail.com

\section{ABSTRACT}

\section{Introduction}

Muscle perfusion is a physiologic process that can undergo quantitative assessment and thus define the range of normal values of perfusion indexes and perfusion reserve. The investigation of the microcirculation has a crucial role in determining the muscle perfusion.

\section{Materials and method}

The study included 30 examinees, 24-74 years of age, without a history of confirmed peripheral artery disease and all had normal findings on Doppler ultrasonography and pedo-brachial index of lower extremity (PBI).

${ }^{99 \mathrm{~m}}$ Tc-MIBI tissue muscle perfusion scintigraphy of lower limbs evaluates tissue perfusion in resting condition "rest study" and after workload "stress study", through quantitative parameters: Inter-extremity index (for both studies), left thigh/right thigh (LT/RT) left calf/right calf(LC/RC) and perfusion reserve (PR) for both thighs and calves.

\section{Results \\ In our investigated group we assessed the normal values of quantitative parameters of perfusion indexes. Indexes ranged for LT/RT in rest study 0.91- 1.05, in stress study 0.92-1.04. LC/RC in rest 0.93-1.07 and in stress study 0.93-1.09. The examinees older than 50 years had insignificantly lower perfusion reserve of these parameters compared with those younger than $50, \mathrm{LC}(\mathrm{p}=0.98)$, and $\mathrm{RC}(\mathrm{p}=0.6)$.}

\section{Conclusion}

This non-invasive scintigraphic method allows in individuals without peripheral artery disease to determine the range of normal values of muscle perfusion at rest and stress condition and to clinically implement them in evaluation of patients with peripheral artery disease for differentiating patients with normal from those with impaired lower limbs circulation.

Key words: muscle perfusion, 99mTc-MIBI scintigraphy, lower limbs, perfusion reserve

\section{INTRODUCTION}

Muscle perfusion is a physiologic process that can undergo quantitative assessment and thus define the range of normal values of perfusion indexes and perfusion reserve. The investigation of the microcirculation has a crucial role in determining the muscle perfusion. The lack of clinical symptoms does not mean that there are no perfusion disturbances in the circulatory system and early information about 
these changes can influence both time and method of treatment and give better therapeutic results [1]. These data create the necessity for searching non-invasive method that would help in determining the deviations from the normal state of perfusion and they depend on impaired vascular blood flow, dysfunctions of its transfer through vascular wall and impaired metabolic activity of muscle cells [2]. The aim is to contribute to early detection of the level of development of the pathology of peripheral vascular disease in different stages. Nuclear medicine scintigraphy method using ${ }^{99 \mathrm{~m}} \mathrm{Tc}-\mathrm{MIBI}$ is still of great interest to identify perfusion disturbances in lower limb muscles in various pathologic condition and it proved high sensitivity and specificity of the examination ( $81 \%$ and $90 \%$ accordingly) $[3,4,5,6]$.

\section{AIMS}

1. To design protocol for diagnostic method of tissue-muscle perfusion scintigraphy of lower limbs with radiopharmaceutical ${ }^{99 m}$ Tc-MIBI in rest and stress condition (after workload);

2. To analyze the parameters of inter-extremity indexes and establish the normal values of lower limb perfusion indexes, as well as perfusion reserve, for both studies.

\section{MATERIALS AND METHOD}

This was a prospective, transversal study performed at the Institute of Pathophysiology and Nuclear medicine "Acad Isak S. Tadzer". The study included 30 patients, $24-74$ years of age. We divided our examinees in 2 groups, according the age: younger than 50 years and older than 50 years of age.

None of the patients had a history of confirmed peripheral artery disease and all had normal findings on Doppler ultrasonography and pedo-brachial index of lower extremity (PBI) in normal range (0.9-1.3). Some of them complained of atypical lower extremity muscle pain, numbness or cold lower extremities.

All patients were treated in accordance with the ethical principles given in the Helsinki declaration. Patients who did not fulfill these criteria or did not give permission for voluntary participation were excluded from the study.

Tissue muscle perfusion scintigraphy with ${ }^{99 \mathrm{~m}}$ Tc-MIBI is a method of quantification of thelower limb muscle perfusion. It has many ad- vantages over other diagnostic modalities: non-invasive, functional method that shows the perfusion status of the limb at microvascular level or at the cellular level. It evaluates tissue perfusion in resting condition "rest study" and after workload "stress study", through quantitative parameters. ${ }^{99 m}$ Tc-MIBI tissue muscle perfusion scintigraphy of lower limbs uses a radiotracer with lipophilic cationic component that after i.v application distributes in the tissue proportionally to the blood flow and traps in the mitochondria.

The rest study included an acquisition of a dynamic phase or tissue-muscle vascularization of both calves after i.v application of $300 \mathrm{MBq}$ of ${ }^{99 \mathrm{~m}} \mathrm{Tc}-\mathrm{MI}-$ $\mathrm{BI}$, (with a time interval of 7 minutes, $15 \mathrm{~s}$ per frame) (7), followed with a whole body scan (WBS) for tissue perfusion of the whole body in posterior position (PA). Stress study was performed afterwards. The examinee was instructed to do 30 flexion/extensions of both feet, followed by i.v application of $600 \mathrm{MBq}$ ${ }^{99 \mathrm{~m} T c-M I B I}$, when the dynamic phase started with the same acquisition protocol as in the rest study. After application of the radiopharmaceutical, the patient performed another 30 flexion/extension of the feet. WBS was performed afterwards.

Tissue muscle perfusion studies were done with planar technique, with two-headed gama camera (MEDISO Nucline SPIRIT), low energy high resolution collimator (LEHR), matrix size $512 \times 1024 \times 16$, speed $15 \mathrm{~cm} / \mathrm{min}$ (WBS). Under these conditions approximately around 1 million impulses were collected in the region of whole body scan.

The following indexes were evaluated with quantitative analyses of WBS, with registered impulses in the ROI, positioned over calves and whole body.

*Inter-extremity index: (for both studies) -left thigh/right thigh (LT/RT) and left calf/right calf (LC/RC) (8). Rectangular regions of interest of equal size were drawn only around the calves in posterior projection. Mean geometric of total pixel value was calculated for each patient.

*Perfusion reserve (PR) for both calves: as a percent of grow of the tissue blood flow in stress study, in comparison with rest study, calculated with the formula (9).

$\operatorname{PR}(\%)=\frac{\text { (radioactivity in calf in stress - radioactivity in calf in rest) }}{\text { radioactivity in calf in rest }} \times 100 \%$

The statistical analysis was performed using the statistical program SPSS for Windows. The following parameters of descriptive statistics were presented for the investigated variables: mean $+/$ standard deviation (SD), minimal and maximal 
values, median with upper and lower quartiles. Differences between the groups were tested using the Student's t test for variables with normal distribution and nonparametric Mann Whitney test for parameters with asymmetrical statistical distribution. Correlation between variables were evaluated with Simple regression analyses. $\mathrm{P}$ values $<0.05$ were considered to be statistically significant.

\section{RESULTS}

Analyzing the symptoms in our group of examinees $18(60 \%)$ had calf pain, $11(36.67 \%)$ complained of numbness, and $7(23.33 \%)$ had cold lower extremities.

Impulses of radioactivity were collected in both thighs and calves with rectangular region of interest drawn over LT, RT, LC, RC. For the thighs the mean impulses ranged from $44786.2 \pm 11318$ for LT, and $45500.5 \pm 10652$ for RT. For the calves lower mean impulses were registered ranging from $19383.2 \pm$ 6154 for LC and $18259.5 \pm 5598$ for the RC. We present the descriptive parameters average values, standard deviation, minimal and maximal values, median with lower and upper quartiles of the counts of radioactivity for each region in Table 1.

We calculated the inter-extremity index for the thighs (left thigh/right thigh) and for the calves (left calf/right calf) for both studies (rest and stress). The mean values \pm SD for indexes ranged for LT/RT in the rest study $0.91-1.05$, and 0.92-1.04 in the stress study. LC/RC in the rest study ranged $0.93-1.07$, while in the stress study 0.93-1.09. We present the descriptive parameters, average values, standard deviation, minimal and maximal values, median with lower and upper quartiles for both LT/RT and LC/RC indexes in rest and stress condition (Table 2.).

There was no significant impact of the age on the inter-extremity index for thighs and calves for both studies (Table 3 ).

The age had no significant impact on the perfusion reserve of $\mathrm{LC}$ and $\mathrm{RC}$. The examinees older than 50 years had insignificantly lower perfusion reserve of these parameters compared with those younger than 50, LC $(\mathrm{p}=0.98), \mathrm{RC}$ $(p=0.6)($ Table 4).

\section{DISCUSSION}

There is a great interest of non-invasive diagnostic techniques for performing studies on the lower limbs perfusion disturbances. First exercise whole-body thallium scintigraphy was used as a useful method to evaluate regional blood flow in patients with suspected peripheral vascular disease. In comparison to the contrast angiography, the test had an overall sensitivity of $80 \%$ and a specificity of $73 \%$. The physiologic severity of a lesion depends on many factors, including abso-

Table 1. Descriptive statistic of radioactivity impulses/counts of LT, RT, LC and RC in rest and stress phase in patients with normal Doppler ultrasonography of lower extremities

\begin{tabular}{|l|c|c|c|}
\hline Variable & mean \pm SD & min $-\mathbf{m a x}$ & median(IQR) \\
\hline LT ${ }^{1}$ rest & $44786.2 \pm 11318$ & $21025-78216$ & $45038(41405-78216)$ \\
LT stress & $138243,5 \pm 25933$ & $81742-187547$ & $140572,5(157824-187547)$ \\
\hline LC rest & $19383.2 \pm 6154$ & $8828-37213$ & $18575(15927-37213)$ \\
LC stress & $81965,6 \pm 22552$ & $47853-132253$ & $78156,5(63540-94927)$ \\
\hline RT rest & $45500.5 \pm 10652$ & $22448-73737$ & $45949(22448-73737)$ \\
RT stress & $141834 \pm 27554$ & $84688-196994$ & $147434(128304-163756)$ \\
\hline RC rest & $18259.5 \pm 5598$ & $3871-33679$ & $18107(15452-21339)$ \\
RC stress & $81472,8 \pm 21563$ & $47277-139865$ & $77332(66276-139865)$ \\
\hline
\end{tabular}

${ }^{1} \mathrm{LT}$, left thigh; LC, left calf; RT, right thigh; RC, right calf;

Table 2. Descriptive statistic of LT/RT, LC/RC indexes in rest and stress phase in patients with normal Doppler ultrasonography of lower extremities

\begin{tabular}{|l|c|c|c|}
\hline Variable & mean \pm SD & $\min -\max$ & median(IQR) \\
\hline LT/RT ${ }^{1}$ rest & $0.98 \pm 0.07$ & $0.78-1.18$ & $0.98(0.94-1.03)$ \\
\hline LC/RC rest & $1.0 \pm 0.07$ & $0.81-1.21$ & $0.99(0.97-1.03)$ \\
\hline LT/RT stress & $0.98 \pm 0.06$ & $0.79-1.08$ & $0.99(0.94-1.01)$ \\
\hline LC/RC stress & $1.01 \pm 0.08$ & $0.75-1.12$ & $1.02(0.94-1.06)$ \\
\hline
\end{tabular}

${ }^{1}$ LT/RT, left thigh/right thigh; LC/RC, left calf/right calf; 
Table 3. Mean values, standard deviations and significance of differences in inter-extremities indexes in rest and stress phase according to age in patients with normal Doppler ultrasonography of lower extremities

\begin{tabular}{|c|c|c|c|}
\hline Variable & age & mean \pm SD & p value ${ }^{2}$ \\
\hline \multirow{2}{*}{ LT/RT ${ }^{1}$ rest } & $<50$ & $0.99 \pm 0.08$ & \multirow{2}{*}{$\mathrm{p}=0.5 \mathrm{~ns}$} \\
\hline & $>50$ & $0.98 \pm 0.07$ & \\
\hline \multirow{2}{*}{$\mathrm{LC} / \mathrm{RC}$ rest } & $<50$ & $1.04 \pm 0.08$ & \multirow{2}{*}{$\mathrm{p}=0.065 \mathrm{~ns}$} \\
\hline & $>50$ & $0.99 \pm 0.05$ & \\
\hline \multirow{2}{*}{ LT/RT stress } & $<50$ & $0.97 \pm 0.03$ & \multirow{2}{*}{$\mathrm{p}=0.4 \mathrm{~ns}$} \\
\hline & $>50$ & $0.98 \pm 0.07$ & \\
\hline \multirow{2}{*}{$\mathrm{LC} / \mathrm{RC}$ stress } & $<50$ & $1.0 \pm 0.04$ & \multirow{2}{*}{$\mathrm{p}=0.37 \mathrm{~ns}$} \\
\hline & $>50$ & $0.99 \pm 0.09$ & \\
\hline
\end{tabular}

${ }^{1} \mathrm{LT} / \mathrm{RT}$, left thigh/right thigh;LC/RC, left calf/right calf;

${ }^{2}$ Significance according to Student t- test; ns, not significant

Table 4. Mean values, standard deviations and significance of differences in perfusion reserve for calves and thighs according to age in patients with normal Doppler ultrasonography of lower extremities

\begin{tabular}{|l|c|c|c|c|}
\hline Variable & age & mean \pm SD & Median(IQR) & \multirow{2}{*}{$\mathbf{p ~ v a l u e}^{2}$} \\
\hline \multirow{2}{*}{ LC\% $^{1}$} & $<50$ & $51.4 \pm 22.19$ & $46.5(37-51)$ & \multirow{2}{*}{$\mathrm{p}=0.98 \mathrm{~ns}$} \\
\cline { 2 - 4 } & $>50$ & $51.15 \pm 23.05$ & $48.5(34-70.5)$ & \\
\cline { 2 - 4 } \multirow{2}{*}{ RC \% } & $<50$ & $49.8 \pm 25.9$ & $40.5(33-54)$ & \multirow{2}{*}{$\mathrm{p}=0.6 \mathrm{~ns}$} \\
\cline { 2 - 4 } & $>50$ & $51.45 \pm 22.55$ & $43(35-64.5)$ & \\
\hline
\end{tabular}

${ }^{1}$ LC, left calf; RC, right calf;

${ }^{2}$ Significance according to Mann-Whitney test; ns, not significant

lute diameter, eccentricity, multiplicity, length and the presence of collateral flow [10].

${ }^{99 \mathrm{~m}}$ Tc-MIBI is generally used to evaluate myocardial perfusion or tumor activity, but it has also proved to be an adequate tracer for skeletal muscle. The sensitivity and specificity of the examination with $\mathrm{Tc}^{99 \mathrm{~m}} \mathrm{MIBI}$ in detection of lower limbs muscles perfusion disturbances is defined as $81 \%$ and $90 \%$ [17-20]. This method allowed to define for the clinical purposes, the ranges of normal values for the lower limbs perfusion indexes (calves and thighs). One of the potential advantages of scintigraphy is that it provides information about the hemodynamic significance of anatomic lesions [11].

In our investigated group we assessed the normal values of quantitative parameters of perfusion indexes, using scintigraphic method of tissue-muscle perfusion with ${ }^{99 m}$ Tc-MIBI. There are little reports concerning this issue and there is no defined range of normal values of lower limbs' perfusion both at rest and stress. We assumed that the examined group of the subjects didn't have any circulatory disturbances in lower limbs. Some of the patients complained of atypical calf muscle pain or coldness of lower extremities. Symmetrical counts were collected in the regions of interest in left and right thigh, as well as in left and right calf, for both rest and stress study. The counts in the calves were twice lower than those in the thighs, because of smaller muscle groups in the calves.

From a qualitative point of view, in the study of Arias et al. the muscles were more visibly depicted after exercise, especially in the calves. From a quantitative point of view, muscle exercise significantly increased ${ }^{99 \mathrm{~m}} \mathrm{Tc}$-sestamibi uptake with respect to rest uptake in the calves $(210.3 \%$ vs. $185.2 \%, \mathrm{p}<0.1$, but not in the thighs $(265.8$ $\%$ vs. $267.8 \%$, n.s.) [12].

The counts increased in all regions of interest in the stress study, as a result of increase in the blood flow, activation of endothelium vasodilatation and other factors included in the maintenance of circulatory system homeostasis. There was no significant difference in the inter-extremity index between young and older patients than 50 years. Slightly lower perfusion reserve were registered in the older patients (group over 50 years of age), insignificant compared with younger cohort individuals. We obtained normal values of tissue-muscle perfusion with radionuclide scintigraphy using 99m Tc-MIBI that can be implemented in analysis of circulatory disturbances in patients with peripheral artery disease. 
In patients with distal and proximal lower limb ischemia, small differences in average values of the perfusion indexes, determined before and after pharmacologic therapy, were observed in the study of Mikosinski et al. There were statically significant differences in the calculated indexes with $p<0.05$. There was an improvement of the average values of all perfusion indexes after the therapy in both groups [13].

Comparing to the group of young patients, a mean increase of $9 \%$ of lower and $7 \%$ of upper range of normal values for calves and thighs perfusion indexes was observed in older patients. Both in patients aged 20-45 and after 50 years of age, a similar, slightly different positive influence of exercise on lower limbs perfusion was observed; $19.5 \%$ in younger patients and $176.8 \%$ in the older ones [11].

Bursak was one of the first authors who gave accent of the importance of the radiopharmaceutical ${ }^{99 \mathrm{~m}} \mathrm{Tc}-\mathrm{MIBI}$ in the use for tissue-muscle perfusion scintigraphy in diagnosing peripheral artery disease of lower limbs. He applied this method in healthy group individuals, in whom he registered and semi-quantitatively proved symmetry of the perfusion in both extremities as well as preserved perfusion reserve (0.52-0.82 for left calf and 0.570.80 for right calf). The opposite was found in the group with $\mathrm{M}$. Burger and diabetes where asymmetry was detected, presence or absence of collateral circulation was noted, as well as absence of perfusion reserve [14].

The range of normal values of the lower limbs perfusion indexes were defined as: calves: at rest - 5.28-8.02, at stress - 4.29-6.32; thighs, at rest - 4.54-7.08 and at stress - 4.00-5.66, using their own radioisotopic method and program for half quantitative assessment of lower limb perfusion at rest and stress [3].

The calculated perfusion reserve in the case study of Manevska et al. revealed a borderline value for the LC 57\%, and a lower perfusion reserve for the RC $42 \%$ (reference values $50-80 \%$ ) [15].

In the study of Tellier et al., scintigraphic calf perfusion symmetry at exercise was an independent predictor of cardiovascular risk, even after adjustment to residual myocardial ischemia, whereas the prevalence of CAD was $56.8 \%$. Moreover, this method might detect silent PAD at a very early stage, perhaps at the phase of endothelial dysfunction, or at least well before arterial stenosis becomes detectable at rest, because this index is measured at a high level of exercise in a very reproducible way as demonstrated by the high values of intraclass correlation coefficients.
There is no additional cost, as it follows myocardial exercise scintigraphy, without special preparation nor other injection or radiotracer [16].

Dabrowsky from the Nuclear medicine Department in Poland, in 2003 showed the superiority of the scintigraphic method compared to the Doppler ultrasonography in evaluation of the effects of lumbar sympathectomy and detection of improving the flow rate in the blood vessels, which cannot be detected by ultrasonography [17].

As compared to the other diagnostic modalities like computed tomographic angiography (CTA), catheter angiography and magnetic resonance angiography, the radioisotope technique by using ${ }^{99 m}$ Tc-MIBI is cost effective and widely available almost at every nuclear medicine center. Regarding the radiation exposure, there was six times less dose in the scintigraphic method than CTA or catheter angiography. Moreover, due to easy availability of ${ }^{99 \mathrm{~m}} \mathrm{Tc}-\mathrm{MIBI}$, it can be used as a follow up tool for the evaluation of the response to treatment [5].

\section{CONCLUSION}

Tissue muscle perfusion scintigraphy with ${ }^{99 \mathrm{~m}} \mathrm{Tc}-\mathrm{MIBI}$ is a non-invasive scintigraphic method that provides in healthy individuals the possibility to determinate the range of normal values of muscle perfusion at rest and stress condition. Thus it allows to clinically implement this values in clinical evaluation of patients with peripheral artery disease for differentiating the patients with the normal from those with impaired lower limbs circulation, especially on microcirculatory level.

\section{REFERENCES}

1. Niewiadomski D, Tryniszewski W, Marzec W, Brocki M, Mikosiński J, Raciborska I, Maziarz Z. The own method and program of isotope quantitatively assessment of perfusion in muscles of upper limbs (initial report). Nuclear Med Rev2014;17,1:13-17

2. Tryniszewski W, Gadzicki M, Maziarz Z. The assessment of the range of normal values of lower limb perfusion indicators at rest and stress with the own radio isotopic method and program. ClinExp Med Lett 2008; 49(2): 107113

3. Miles KA, Barber RW, Wraight EP, Cooper M, Appleton DS. Leg muscle scintigraphy with ${ }^{99} \mathrm{mTc}$ MIBI in the assessment of pe- 
ripheral vascular (arterial) disease. Nucl Med Comm 1992; 13: 593- 603.

4. Sumarriva N. Stress And Rest Spect/ct Imaging For Evaluation Of Lower Extremity Perfusion: An Index For Evaluation Of Microvascular And Macrovascular Disease (2014). Yale Medicine Thesis Digital Library. Paper 192

5. Rasheed R. Molecular Perfusion Imaging with ${ }^{99} \mathrm{mTc}$-MIBI Lower Limb Muscle SPECT: In Diagnosis and Follow up of Peripheral Arterial Diseases (PAD). J Diabetes Metab 2015, 6:3

6. Tan YZ, Kılıç S, Temiz A, Özdemir S, Kurt T Cevizci S. Comparison of Ankle-Brachial Index and Lower Limb Perfusion Reserve in Patients with Behçet's Disease. Austin J Nucl Med Radiother - Volume 3 Issue 1 - 2016

7. Čizmić M, Pucar D, Zoranović. Assessment of lower extremities ischaemic disease by thalium 201 perfusion scintigraphy in patients with diabetic angipathy. Vojnosanit Pregl 2010; 68(2): 161-165.

8. Kuśmierek J, Dąbrowski J. Bieńkiewicz M, Szumiński R, Plachcińska A. Radionuclide assessment of lower limb perfusion using. ${ }^{99 \mathrm{~m}} \mathrm{Tc}-\mathrm{MIBI}$ in early stages of atherosclerosis. Nuclear Medicine Review 2006; 9(1):18-23.

9. Celen YZ, Zincirkeser S. Invistigation of Microvascular Perfusion of the Lower Extremities of Neuropathy Patients with ${ }^{99 \mathrm{~m}} \mathrm{Tc}-\mathrm{MIBI}$. Hell. J Nucl Med 2000; 3:160-162.

10. Segall G.M, Lang E. V, Lennon S. E, Stevick C. D. Functional Imaging of Peripheral Vascular Disease: A Comparison Between Exercise Whole Body Thallium Perfusion Imaging and Contrast Arteriography. J NucI Med 1992;33:1797

11. Tryniszewski W, Gadzicki M, Maziarz Z. Determination of normal values range for lower limbs muscles perfusion indexes at Rest and after exercise in patients after 50 years of age, with the possibility of assessment of age influence on these values in case of their clinical application. Clin Exp Med Lett 2009; 50(1)49-54.

12. Arias J.A, García S, Cuadrado M.L, Pardo C, Lapeña G, Carreras J. L ${ }^{99} \mathrm{mTc}$-MIBI muscle imaging and approach to assess functional anatomy of lower limb muscles. JOURNAL OF NEUROLOGY AND NEUROSCIENCE. 2010;1:1-4.

13. Mikosinski J, Lesiak T, Brocki M, Maziarz Z, Gadzicki M, Tryniszewski W. Multidirectional assessment of medical treatment influence on lower limb perfusion in patients suffering from obliterative atheromatosis. Acta Angiol. 2007;13(4):144-155

14. Bursak Sayman H, Urgancioglu I. Muscle Perfusion with Technetium-MIBI in lower Extremity Perifrial Arterial Diseases. J Nucl Med 1991; 32:1700-1703.

15. Manevska N, Pop Gjorceva D, Ahmeti I, Todorovska L, Stojanoski S, Zdraveska Kocovska. Tissue-Muscle Perfusion Scintigraphy of the Lower Limbs in a Patient with Type 2 Diabetes Mellitus and Peripheral Arterial Disease. M. Mol Imaging Radionucl Ther. 2016 Feb; 25(1): 42-46.

16. Tellier P, Lecouffe P,Zureik M. Scintigraphic Calf perfusion symmetry at exercise: a new noninvasiveindex for prediction of cardiovascular events in high-risk subjects? Presented in part at the 91th Annual Meeting of the Radiological Society of North America, 27 nov-2 déc 2005

17. Dąbrowski J, Mikosiński J, Kuśmierek J. Scintigraphic and ultrasonographic assessment of the effect of lumbar sympathectomy upon chronic arteriosclerotic ischaemia of lower extremities. Nuclear Medicine Review 2003 6(1):17-22. 


\section{НОРМАЛНИ ВРЕДНОСТИ НА ИНДЕКСОТ НА ПЕРФУЗИЈА НА ТКИВНИТЕ МУСКУЛИ НА ДОЛНИТЕ ЕКСТРЕМИТЕТИ ДОБИЕНИ СО СЦИНТИГРАФСКИ МЕТОД}

Невена Маневска' ${ }^{1}$ Синиша Стојаноскиํㅡ, Даниела Поп Горчева ${ }^{1}$, Лидија Тодоровска'ㄹ, Даниела Миладинова ${ }^{1}$, Бети Зафирова ${ }^{3}$

${ }^{1}$ Институт за патофизиологија и нуклеарна медицина, Акад „Исак С. Таџер“, Медицински факултет, Скопје, Р. Македонија

${ }^{2}$ Институт за медицинска физиологија и антропологија, Медицински факултет, Скопје, Р. Македонија

${ }^{3}$ Институт за епидемиологија и биостатистика со медицинска информатика, Медицински факултет, Скопје, Р. Македонија

\section{Резиме}

\section{Вовед}

Мускулната перфузија е физиолошки процес, кој може да подлегне на квантитативна проценка и со тоа да се дефинираат норманите вредности на перфузионите индекси и перфузионата резерва. Иследувањето на микроциркулацијата има круцијална улога во одредувањето на мускулната перфузија.

\section{Материја и метода}

Студијата вклучува 30 испитаници, на возраст 24-74 години, без историја на потврдена периферна артериска болест, со нормален наод на Doppler ултрасонографија и педо-брахијален индекс на долните екстремитети (ПБИ).

99мТц-МИБИ ткивно-мускулната перфузиона сцинтиграфија на долните екстремитети ја евалуира ткивната перфузија во услови на мирување, „рест“ студија, како и во услови на базално оптеретување, „стрес“ студија, преку квантитативни параметри: интер-екстремитетен индекс (за двете студии) лево натколено/десно натколено (ЛН/ДН), лево потколено/десно потколено (ЛП/ДП) и перфузиона резерва (ПР) за обете натколени и потколени регии.

\section{Резултати}

Во нашата испитувана група ги проценивме квантитативните вредности на перфузионите индекси. Индексите изнесуваа за ЛН/ДН во рест 0.91- 1.05, во стрес 0.92-1.04. ЛП/ДП во рест 0.93-1.07, додека во стрес 0.93-1.09. Испитаниците постари од 50 години имаа несигнификантно помала перфузиона резерва на овие параметри споредено со испитаниците помлади од 50години, ЛП ( $\mathrm{p}=0.98)$ и ДП (p=0.6).

\section{Заклучок}

Оваа неинвазивна сцинтиграфска метода овозможува кај индивидуи без периферна артериска болест, да се одредат нормалните вредности на мускулната перфузија во услови на мирување и оптоварување и истите клинички да се имплементираат во евалуација на пациенти со периферна артериска болест, со цел диференцирање на пациенти со нормална и нарушена циркулација на долните екстремитети.

Клучни зборови: мускулна перфузија, 99мТц-МИБИ сцинтиграфија, долни екстремитети, перфузиона резерва 